DOI https://doi.org/10.30525/978-9934-588-79-2-1.46

\title{
THE HOUSING STRUCTURE AND THE HEAT PUMP MARKET IN EUROPEAN COUNTRIES
}

\author{
Teslenko O. I. \\ Candidate of Technical Sciences (Ph. D.), \\ Senior Scientific Researcher at the Department of Energy Efficiency \\ and Optimization of Energy Consumption \\ Institute of General Energy of National Academy of Sciences of Ukraine \\ Davydova A. V. \\ Student at the Department of Heat Engineering and Energy Saving \\ National Technical University of Ukraine \\ «Igor Sikorsky Kyiv Polytechnic Institute» \\ Kyiv, Ukraine
}

The development of heat pumps (HP) ensures the widespread use of renewable energy sources. As a result of the widespread use of solar and wind power plants, the production of heat energy using electric HP will be fuel-free and will reduce emissions of greenhouse gases and other harmful components.

There are aerothermal, geothermal, hydrothermal types of HP. The consumer uses heat energy from HP for space heating and hot water supply (Sanitary Hot Water). In European countries, various types of HP are widely used. Analyzing this topic, we used the annual reports of the European Heat Pump Association (EHPA) [1]. There is a positive trend in the development of the HP market, according to our data, the number of installed heating units reached 14 million units as of September 2020.

According to reports from EHP (2019), in 21 European countries the number of installed HP units reached 12,800,000. Units (annual growth + $10 \%$ ) with a total thermal capacity of $444 \mathrm{GW}$, which allowed the use of $140 \mathrm{TWh}$ of renewable energy, led to a decrease in greenhouse gas emissions by 35.8 million tons $\mathrm{CO}_{2}$-eq and provided 68 thousand jobs in the segment of manufacturing, installation, commissioning and maintenance of HP. According to the sources of low potential heat, the sale of aerothermal and geothermal HP prevails (over 95\%). The sales leaders are France, Italy and Spain, which account for 50\% of all HP sold in Europe. The top tenselling countries, which additionally include Sweden, Norway, Germany, Finland, Denmark, the Netherlands and Poland, account for almost $90 \%$ of 
all HP sold. The leaders in sales of HP per capita (2018) are Norway (48 units per 1000 households), Estonia (29.3) and Finland (24.5). With about 244 million residential buildings in Europe, the HP market share in the building stock is around 5\%. EHPA estimates that potential sales of HP for the whole of Europe exceed 6,000,000 units per year [1].

The aim of our research was to establish the influence of the structure of the housing stock on the distribution of certain types of HP in European countries.

The baseline data on the structure of the housing stock in European countries was the information from Eurostat [2] and the HP market from EHPA [1], which presented in Table 1.

The market structure of HP is different in individual countries. Consider the top - 5 countries in terms of sale: France, Italy, Sweden, Norway and Germany. The factors influencing these statistics are climatic conditions, government incentives for new technologies, structure of the housing stock in individual countries. For example, in France the largest share occupied by the use of the "Air-water» type, which is $33 \%$ of the total. In Italy, the most used is "Air-air», accounting for $88 \%$ and is widely used throughout the country. Sweden is such a distribution that in percentage terms, all types roughly divided. Norway has different climatic conditions compared to previous countries, through which the division is completely different, 94\% falls on the use of the «Air-air» type. In Germany, it divided approximately equally between two types: «Air-water» and «Earth - water», which is quite understandable based on climatic conditions and geographical location.

The method of correlation analysis used software product Microsoft Excel [3].

Correlation coefficients and approximate linear dependences described for each type of HP for countries, which describe the impact of the housing stock (Table 2).

Based on the results of the calculations, an indicative graph built depending on the distribution of types of heat pumps on the structure of the country's housing stock (figure).

Analyzing the information that we used for our work, we concluded that for HP type "Air-water» (space heating) $r=-0.33$, which suggests that the correlation is average, such HP are used both in detached estates and in multi-apartment houses (Flat).

For HP type «Air-air» $r=0.24$, which speaks for a close to average dependence, is more typical for countries with a predominant share of apartment buildings (range from $30 \%$ to $70 \%$ ). 
Table 1

Structure of the heat pump markets and the housing in European countries [1, 2]

\begin{tabular}{|c|c|c|c|c|c|c|}
\hline \multirow{2}{*}{ Country (code) } & \multicolumn{5}{|c|}{ Heat Pump: Type, quantity units, thousands } & Housing \\
\cline { 2 - 7 } & $\begin{array}{c}\text { To- } \\
\text { tal }\end{array}$ & $\begin{array}{c}\text { Air - } \\
\text { water }\end{array}$ & $\begin{array}{c}\text { Air - } \\
\text { air }\end{array}$ & $\begin{array}{c}\text { Earth - } \\
\text { water }\end{array}$ & $\begin{array}{c}\text { Sanitary } \\
\text { hot } \\
\text { water }\end{array}$ & $\begin{array}{c}\text { Flat } \\
\text { part, } \\
\text { \% }\end{array}$ \\
\hline France (FR) & 2000 & $656(33)$ & $589(29)$ & $109(5)$ & $455(23)$ & 33 \\
\hline Italy (IT) & 1700 & $4(0)$ & $\begin{array}{c}1500 \\
(88)\end{array}$ & $3(0)$ & $10(1)$ & 52 \\
\hline Sweden (SE) & 1700 & $149(9)$ & $778(46)$ & $526(31)$ & $0(0)$ & 45 \\
\hline Norway (NO) & 1000 & $41(4)$ & $939(94)$ & $46(5)$ & $0(0)$ & 21 \\
\hline Germany (DE) & 947 & $416(44)$ & $1(0)$ & $351(37)$ & $174(18)$ & 57 \\
\hline Finland (FI) & 795 & $22(3)$ & $635(80)$ & $111(14)$ & $0(0)$ & 34 \\
\hline Spain (ES) & 581 & $2(0)$ & $508(87)$ & $0(0)$ & $14(2)$ & 66 \\
\hline Denmark (DK) & 280 & $27(10)$ & $195(70)$ & $32(11)$ & $16(6)$ & 32 \\
\hline Austria (AT) & 278 & $87(31)$ & $0(0)$ & $103(37)$ & $82(29)$ & 45 \\
\hline Switzerland (CH) & 267 & $143(54)$ & $0(0)$ & $95(36)$ & $28(10)$ & 63 \\
\hline United Kingdom & 183 & $136(74)$ & $0(0)$ & $32(17)$ & $2(1)$ & 15 \\
\hline (UK) & 146 & $9(6)$ & $123(84)$ & $14(10)$ & $0(0)$ & 62 \\
\hline Estonia (EE) & 141 & $0(0)$ & $124(88)$ & $0(0)$ & $6(4)$ & 45 \\
\hline Portugal (PT) & 136 & $11(8)$ & $13(10)$ & $37(27)$ & $55(40)$ & 44 \\
\hline Poland (PL) & 115 & $58(50)$ & $0(0)$ & $47(41)$ & $9(8)$ & 19 \\
\hline Netherlands (NL) & 84 & $61(73)$ & $0(0)$ & $22(26)$ & $0(0)$ & 52 \\
\hline Czech Republic \\
(CZ)
\end{tabular}

Table 2

The results of correlation analysis

\begin{tabular}{|c|c|c|c|}
\hline Type HP & Correlation & Dependence & Approximation \\
\hline Air-water & $-0,33$ & average & $\mathrm{y}=-0,3927 \times \mathrm{x}+0,495$ \\
\hline Air-air & 0,24 & close to average & $\mathrm{y}=0,3861 \times \mathrm{x}+0,3961$ \\
\hline Earth - water & $-0,06$ & absent & $\mathrm{y}=0,1939 \times \mathrm{x}+0,1711$ \\
\hline Hot water & $-0,03$ & absent & $\mathrm{y}=0,0325 \times \mathrm{x}+0,1306$ \\
\hline
\end{tabular}




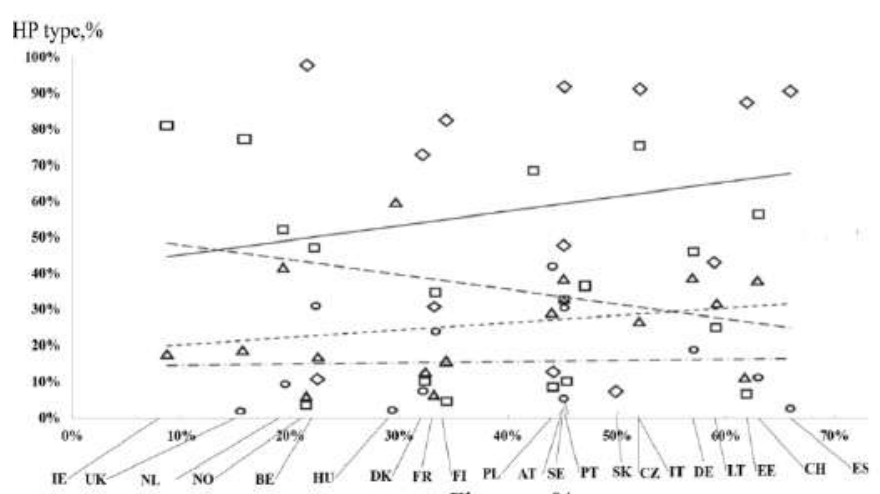

Flat part, $\%$

$$
\begin{aligned}
& \text { HP type: } \square-\text { air - water, \% } \\
& \text { line: - - - - air - water, } \\
& \Delta \text { - earth - water, } \% \\
& \text { o - hot water, } \% \\
& \diamond-\text { air - air, \% } \\
& \text { - earth - water, } \\
& -\cdot \quad-\text { hot water, } \\
& \text { - - air - air. }
\end{aligned}
$$

\section{Fig. Distribution of HP types from the share of flats in the housing structure of European countries (2017)}

For HP type «Sanitary Hot water» $r=0.03$ (dependence is absent): more typical for the moderate part of apartment buildings (from $20 \%$ to $50 \%)$.

For HP type «Earth - water»: there is no indicator according to the correlation coefficient, for grouping the share of apartment buildings (from $45 \%$ to $65 \%$ ), a significant proportion of distribution is characteristic (25-45\%), and for grouping the share of apartment buildings (from 10\% to $35 \%)$ a significant share of distribution is characteristic (5-20\%).

\section{References:}

1. European Heat Pump Association. Stat. EHPA. URL: http://www.stats.ehpa.org/hp_sales/cockpit/

2. European Commission. Eurostat. Distribution of population be degree of urbanisation, dwelling type and income group - EU-SILC survey. URL: https://appsso.eurostat.ec.europa.eu/nui/submitViewTableAction.do

3. Ronald W. Larsen. Engineering with Excel (First Edition). Prentice Hall, Inc., 2002. - 544 p. 